\title{
Groundwater Regulation and the Development of Alternative Source Waters to Prevent Subsidence, Houston Region, Texas, USA
}

\author{
Christina Petersen $^{1}$, Michael J. Turco ${ }^{1}$, Alia Vinson ${ }^{2}$, Joseph A. Turco ${ }^{4}$, Alan Petrov ${ }^{1}$, and Mark Evans ${ }^{3}$ \\ ${ }^{1}$ Harris-Galveston Subsidence District, Friendswood, Texas, USA \\ ${ }^{2}$ Allen Boone Humphries \& Robinson LLP, Houston, Texas, USA \\ ${ }^{3}$ North Harris County Regional Water Authority, Houston, Texas, USA \\ ${ }^{4}$ Northeastern University, Boston, MA, USA
}

Correspondence: Michael J. Turco (mturco@subsidence.org)

Published: 22 April 2020

\begin{abstract}
Since the development of the coastal areas near present-day Houston, Texas, USA, subsidence has been a significant public policy concern. Subsidence in this area is caused by the extraction of groundwater from the Coastal Lowlands aquifer system, locally referred to as the Gulf Coast Aquifer. Concerns associated with subsidence in the Houston area include coastal inundation from storm surge, inland flooding, and critical infrastructure damage. The Houston area receives about $126 \mathrm{~cm}$ of precipitation each year, making flooding a critical issue in the region. The Houston area is the 4th largest city in the United States with a population of about 6.89 million (2017) and has a total water demand of about $4 \mathrm{Mm}^{3}$ per day (2017). In the 1950s the City of Houston began the development of several reservoirs to provide water for the rapidly growing city. In 1975, following decades of subsidence totaling over $3 \mathrm{~m}$, the Harris-Galveston Subsidence District (District) began regulating the use of groundwater and shifting the primary water supply for the region from groundwater to treated surface water to cease on-going and prevent future subsidence. Leveraging the alternative resources developed by the City of Houston in the 1950s, the District's regulatory framework focuses on spatial prioritization and the systematic conversion to alternative source waters. The District's regulatory plan includes three planning areas. Currently, the regional water authorities and the City of Houston are developing nearly five billion dollars (USD) in infrastructure to produce and deliver an additional $1.2 \mathrm{Mm}^{3}$ per day of treated surface water to Houston and the surrounding communities. Resource development, public engagement, and political foresight have resulted in a reasonable approach to shift source waters and implement a plan to dramatically reduce and stop subsidence in the region. Figure 2 presents subsidence rates (2017) by regulatory area. Results show that the implementation of the regulatory program has substantially slowed subsidence in Areas 1 and 2, where full conversion has taken place. Planning the future water needs of the Houston area resulted in a robust and effective collaboration between the regulated community and the District. Analysis of historical source water use, aquifer response, and subsidence in the Houston area shows that the reasonable management of groundwater use in the Houston region is vital for the long-term prevention of subsidence and increases the resilience of the entire region.
\end{abstract}




\section{Introduction}

The Houston Region has relied on groundwater as a primary source of water since the early 1900s. During and following the economic boom of the 1940s, rapid population expansion and increased water demand resulted in potentiometric water-level declines in the Chicot and Evangeline aquifer of 76- and $91 \mathrm{~m}$ respectively from 1943-1977 (Gabrysch, 1982).

The reliance on groundwater and subsequent subsidence that was caused by its regional development resulted in the creation of the Harris-Galveston Subsidence District in 1975 and the Fort Bend Subsidence District in 1989.

The Harris-Galveston Subsidence District's mission is to regulate the use of groundwater in the Houston Region (Harris and Galveston counties) to cease ongoing and prevent future subsidence that can lead to infrastructure damage and contribute to flooding.

The Harris-Galveston Subsidence District ("District") regulates groundwater use by subdividing Harris and Galveston county into three regulatory areas: Area 1 includes the Houston Ship Channel, Industrial Corridor, and coastal areas; Area 2 is primarily an urban intermediate area that includes the Texas Medical Center; and Area 3 includes the remaining areas of the District in northern and western Harris County. In 2018, Area 3 used nearly $6.96 \times 10^{5} \mathrm{~m}^{3}$ of groundwater each day, nearly six times the other two areas combined. Overall, the total water demand in the District in 2018 , including all sources of water, was about $3.79 \times 10^{6} \mathrm{~m}^{3}$ per day.

\section{Groundwater}

Groundwater is derived from the Coastal Lowland Aquifer, locally referred to as the Gulf Coast Aquifer System, and includes three primary water bearing units, the Chicot, Evangeline, and Jasper aquifers (Fig. 1). The aquifers are comprised of inter-bedded lenticular lenses of sand, silt, and clay which are not regionally extensive and have a highly variable thickness (Chowdhury and Turco, 2006) in the Houston Area.

The Evangeline aquifer is the most widely utilized aquifer in the Houston area accounting for more than half of all the groundwater used. The Chicot aquifer is used appreciably in the areas closer to the coast, although it can be used for domestic supply north of the District. The Jasper aquifer is used primarily in the northern areas of the District where the unit is closer to the surface and better quality.

\section{Compaction and Subsidence}

Subsidence has been occurring in the Houston Region since the early 1900s. Located along the Gulf of Mexico, the topography of the region is a flat coastal plain with little relief that generally slopes about $0.2 \mathrm{~m} \mathrm{~km}^{-1}$.
The first documented case study in the Houston Region linking shallow fluid withdrawal and land surface subsidence occurred at the Goose Creek Oilfield near Baytown, TX (Pratt and Johnson, 1926). Oil and water production at this site occurred at depths up to about $1500 \mathrm{~m}$ in as old as Miocene-age sediments. This area experienced nearly a meter of subsidence over about a three-year period, and dramatic surficial fissures.

As the Houston area developed, experiencing dramatic growth in the 1940s during Word War II and sustaining the regional growth through the present, groundwater resources were the primary source water for the region and subsidence in the region reached magnitudes of concern.

Historically, subsidence has occurred over a broad region that encompasses most of the City of Houston with specific areas of increased magnitude. The Houston ship channel, a large industrial and commerce area in Houston that is part of the second largest port (by tonnage) in the United States, is located near the center of an area where over $3 \mathrm{~m}$ of subsidence as occurred since 1906.

Regulatory controls in Harris, Galveston and Fort Bend County are implemented based on a specific portion of an entities total water demand sourced from groundwater, with the remaining portion sourced from an alternative source that does not contribute to subsidence (treated surface water, reclaimed water, etc.) In 2019, regulatory requirements in $\mathrm{Ar}$ eas 1 and 2 allow groundwater to be utilized for $10 \%$ and $20 \%$ respectively of the water users total water demand. In Area 3, water users without a groundwater reduction plan are regulated to the same requirements as Area 2. However, if a water user has an approved groundwater reduction plan then groundwater may provide up to $70 \%$ of their total water demand, with future reductions in the allowed percentage of groundwater to $40 \%$ and $20 \%$ in 2025 and 2035, respectively. This regulatory approach has been greatly successful in reducing subsidence rates while accounting for the time needed to develop infrastructure to treat and convey water throughout the Houston region (Figs. 2 and 3).

\section{Alternative Water Supplies}

In the 1950s the City of Houston began the development of several reservoirs to provide water for the rapidly growing region within the San Jacinto and Trinity River Basins. Other entities in the region have also developed surface water supply from the Trinity, San Jacinto, and Brazos Rivers. The treatment plants served by these surface water sources are operated by the City of Houston, City of Sugar Land, City of Richmond, the Gulf Coast Water Authority, the Brazosport Water Authority, and others.

To meet the Harris-Galveston and Fort Bend Subsidence Districts' regulatory requirements to convert from groundwater to surface water, the City of Houston and four regional water authorities - Central Harris County Regional Water 


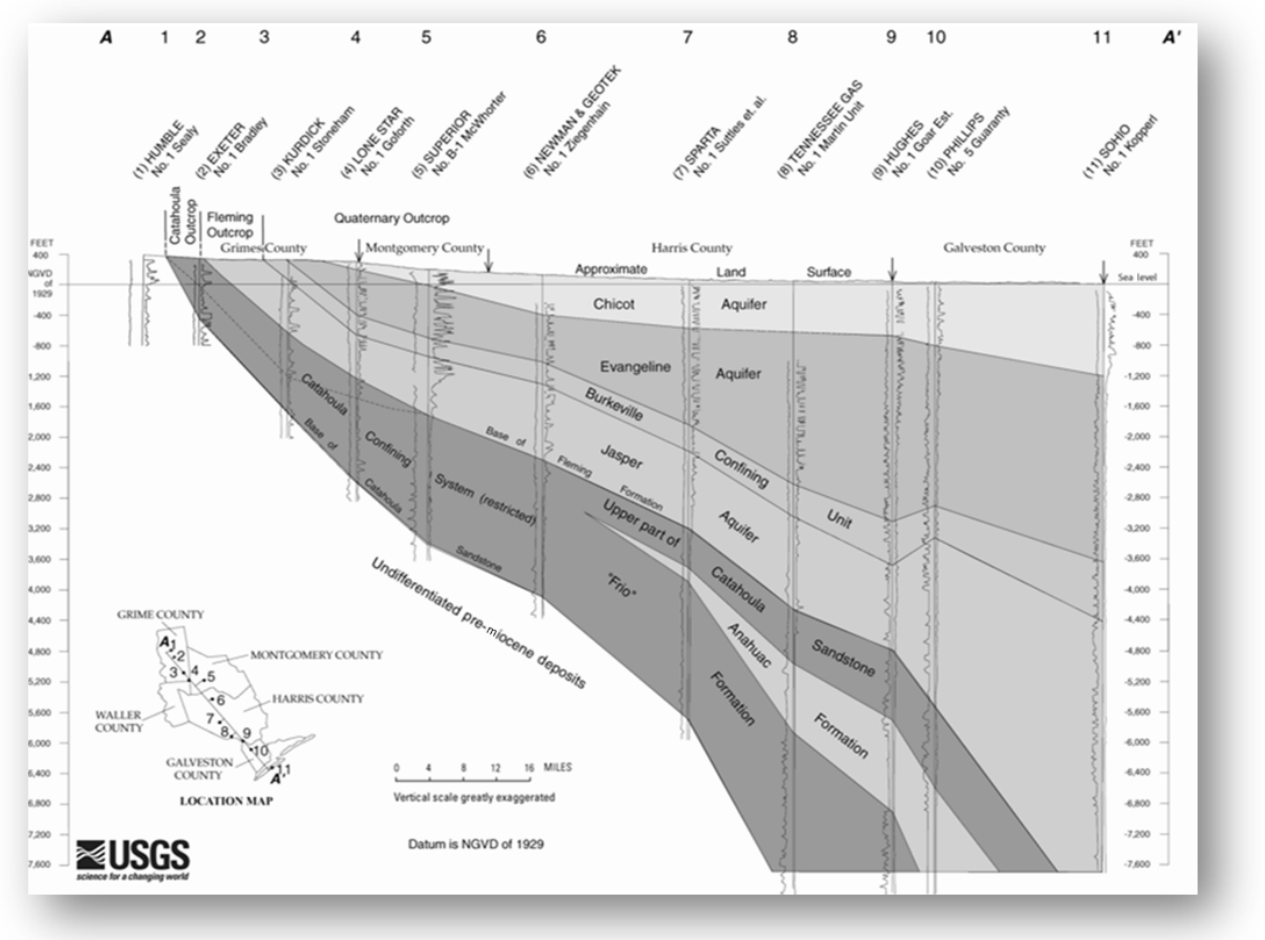

Figure 1. Hydrogeologic cross-section of the Gulf Coast aquifer system in the Houston Region, Texas, USA (modified from Kasmarek, 2014).

Authority, North Fort Bend Water Authority, North Harris County Regional Water Authority, and West Harris County Regional Water Authority (collectively, the "Water Authorities") are working together to plan, design, construct, and finance several major infrastructure projects. These projects are regional in scale and are interrelated. All the projects must be constructed on the same timeline to ensure that surface water will be available to northern and western Harris County and northeast Fort Bend County to comply with the Subsidence District's regulatory conversion schedule.

The first project is called the Luce Bayou Interbasin Transfer Project ("Luce Bayou"). Luce Bayou is currently under construction and will pump untreated surface water from the Trinity River through a series of canals and water pipelines to Lake Houston (northeast of the City of Houston). Luce Bayou is being constructed by the Coastal Water Authority, but the project is being funded by the entities that will be purchasing the transferred water, which includes the City of Houston and the Water Authorities.

The second project is called the Northeast Water Purification Plant ("NEWPP") Expansion Project. The NEWPP expansion is a design-build project under construction on the banks of Lake Houston. The project will expand the existing plant's capacity from $3.03 \times 10^{5} \mathrm{~m}^{3}$ per day up to $1.51 \times 10^{6} \mathrm{~m}^{3}$ per day, in order to treat the raw surface water conveyed by Luce Bayou into Lake Houston (Fig. 4). The
City of Houston is the owner of this project, but the Water Authorities have purchased $84 \%$ of the capacity of the NEWPP and are each paying their respective shares of the costs.

The third project is a transmission line called the Northeast Transmission Line ("NETL"), which will convey treated water from the NEWPP into central and northern Harris County. The NETL is expected to be primarily a $2.74 \mathrm{~m}$ diameter steel water line that is approximately $43.5 \mathrm{~km}$ in length. The City of Houston is the owner of this project, but the North Harris County Regional Water Authority and the Central Harris County Regional Water Authority have purchased capacity in the line and are each paying their respective shares of the costs (the West Harris County Regional Water Authority and the North Fort Bend Water Authority are also participating in the initial segment of the NETL).

The fourth project is a transmission line (and two pump stations) called the Surface Water Supply Project ("SWSP"), which will convey treated water from the NEWPP into western Harris County and north-eastern Fort Bend County. The SWSP is expected to be primarily a $2.4 \mathrm{~m}$ diameter steel water line that is approximately $64 \mathrm{~km}$ in length. The West Harris County Regional Water Authority is the owner of this project, but the North Fort Bend Water Authority has purchased capacity in the line and is paying its share of the costs. 


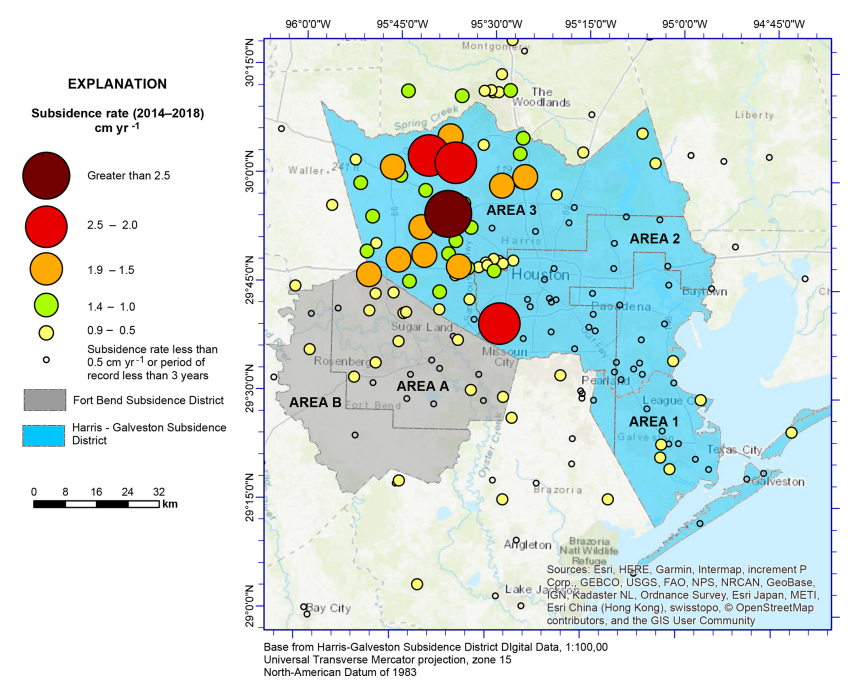

Figure 2. Annual rate of ellipsoid height estimated from available GPS data measured at monitoring location within the Houston Region, 2014-2018. (Thompson et al., 2019, base courtesy of (C) ESRI).
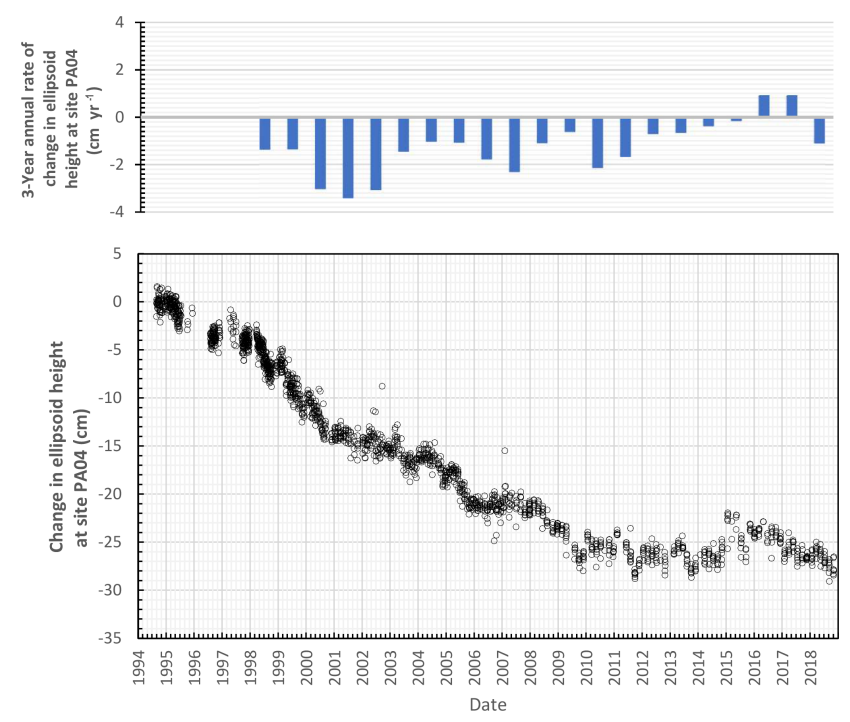

Figure 3. Measured and estimated annual rate of change in ellisoid height at Harris-Galveston Subsidence District monitoring site PA04 located near Memorial Village, TX, 1994-2019.

In addition to the four projects described above, the City of Houston and the Water Authorities are each designing and constructing their own distribution systems to convey the treated surface water to their customers.

Both the NETL and the SWSP are massive transmission lines running through densely populated and congested areas. The transmission lines must be installed in narrow easement corridors, which adds to the complexity and ultimately the cost of the projects. Currently (2019), both the NETL and the SWSP are under design and are expected to commence construction soon.

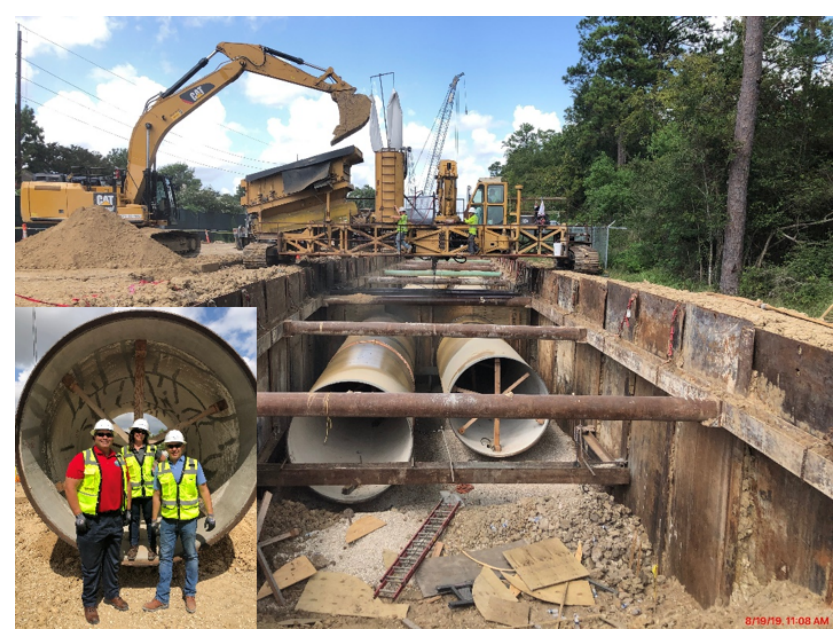

Figure 4. (main) Photo of construction of dual $2.74 \mathrm{~m}$ raw water lines from Lake Houston to the Northeast Water Purification Plant (courtesy Steve Berckenhoff); (inset) Subsidence District officials near raw water pipeline (courtesy Harris-Galveston Subsidence District).

Due to the technical and financial challenges associated with these projects, it is critical for the City of Houston and the Water Authorities to have regulatory certainty from the Harris-Galveston and Fort Bend Subsidence Districts. The transmission and treatment capacity have been sized to meet the current District's conversion requirements in 2025 and 2035.

These interrelated regional projects are planned to be completed by 2025, when the next conversion requirements of the Harris-Galveston and Fort Bend Subsidence Districts go into effect. While these projects are time consuming and costly (the costs are likely to total close to USD 5 Billion), the City of Houston, Coastal Water Authority, and the Water Authorities have been able to work together to create economies of scale and maximize efficiencies. This regional effort could serve as a model for other locations seeking to address large scale water supply needs.

\section{Conclusions}

The Gulf Coast Aquifer System in the State of Texas, USA has been a primary source of water for the Houston region since development began early in the 1900's Since that time extensive data collection and research has been conducted to better understand the impact of anthropogenic stress on the aquifer's water levels, compaction, and subsidence. The State of Texas created a unique regulatory agency to address the issue by regulating the amount of ground water use in Harris, Galveston, and Fort Bend counties. Since the creation of the Subsidence Districts, areas nearest the coast have been converted to alternative source waters and subsidence rates of declined significantly. 
Currently, in more inland areas of the District's, extensive water infrastructure development is ongoing. These efforts require the coordination of multiple regional water authorities and the City of Houston to ensure the compliance with planned future conversion requirements to further reduce the amount of groundwater use. This effort is planned to be completed before the next regulatory conversion deadline in 2025. This regional effort that includes coordination and collaboration amongst the regulated community as well as the coordination between the regulator and regulated community serves as a good model for similar infrastructure development.

Data availability. The GPS data and analysis presented in this paper are published annually by the Harris-Galveston Subsidence District, archived locally, and are available from the District upon request.

Author contributions. CP, MJT, and AP provided significant contribution to the description of the subsidence issue in the Houston area, interpretation of the subsidence data, and integration of improved infrastructure. AV and ME provided significant contributions on the development of alternative source waters and infrastructure to comply with regulatory requirements. JAT developed the computer python code for the period of record analysis shown in Fig. 3.

Competing interests. The authors declare that they have no conflict of interest.

Special issue statement. This article is part of the special issue "TISOLS: the Tenth International Symposium On Land Subsidence - living with subsidence". It is a result of the Tenth International Symposium on Land Subsidence, Delft, the Netherlands, 17-21 May 2021.

\section{References}

Chowdury, A. H. and Turco, M. J.: Geology of the Gulf Coast aquifer, Texas, chap. 2, edited by: Mace, R. E., Davidson, S. C., Angle, E. S., and Mullican, W. F., Aquifers of the Gulf Coast of Texas: Texas Water Development Board Report 365, 23-50, 2006.

Gabrysch, R. K.: Ground-Water Withdrawals and Land-Surface Subsidence in the Houston-Galveston Region, Texas, 1906-80, U.S. Geological Survey, Open-File Report 82-571, 68 p., 1982.

Kasmarek, M. C. and Johnson, M. R.: Groundwater withdrawals 1976, 1990, and 2000-10 and land-surface-elevation changes 2000-10 in Harris, Galveston, Fort Bend, Montgomery, and Brazoria Counties, Texas: U.S. Geological Survey Scientific Investigations Report 2013-5034, 17 p., 2013.

Pratt, W. E. and Johnson, D. W.: Local Subsidence of the Goose Creek Oil Field, J. Geol., 34, Part 1, 577-590, 1926.

Thompson, R., Petersen, C., and Chrismer, M.: 2018 Annual Groundwater Report: Harris-Galveston Subsidence District, available at: https://hgsubsidence.org/wp-content/uploads/2019/ 11/2018-HGSD-Annual-Groundwater-Report.pdf, last access: 31 July 2019. 